\title{
„Ha csak úgy kiköltöztetjük az embereket, egymás nélkül elvesznek." Erőforrások, korlátok és ezek térbelisége a roma szegregátumokban lakók számára: egy hazai város példája
}

\section{"If we just move people out, they will be lost without each other." Resources, limits and their spatial distribution for the Roma underclass living in urban ghettos: the case of a major Hungarian city}

\author{
TÓTH JANKA, MÉREINÉ BERKI BOGLÁRKA, \\ MÁLOVICS GYÖRGY, JUHÁSZ JUDIT, BOROS LAJOS
}

TÓTH Janka: független kutató; 6781 Domaszék, Tanya 849.; tothjanka@gmail.com MÉREINÉ BERKI Boglárka: PhD-hallgató, Szegedi Tudományegyetem, Gazdaságtudományi Kar Kutatóközpont; 6722 Szeged, Kálvária sgt.1.; mereine.berki.boglar@eco.u-szeged.hu MÁLOVICS György: egyetemi docens, Szegedi Tudományegyetem, Gazdaságtudományi Kar Kutatóközpont; 6722 Szeged, Kálvária sgt. 1.; malovics.gyorgy@eco.u-szeged.hu JUHÁsZ Judit: PhD-hallgató, Szegedi Tudományegyetem, Gazdaságtudományi Kar, Közgazdaságtani Doktori Iskola; 6722 Szeged, Kálvária sgt. 1.; judit.juhasz@eco.u-szeged.hu BOROS Lajos: egyetemi adjunktus, Szegedi Tudományegyetem, Gazdaság- és Társadalomföldrajz Tanszék; 6722 Szeged, Egyetem u. 2.; borosl@geo.u-szeged.hu

KULCSSZAVAK: városi szegregáció; underclass; roma; erőforrások; antiszegregáció

ABSZTRAKT: A lakóhelyi szegregáció és térben koncentrált mélyszegénység komoly probléma a hazai városok számára. A tapasztalatok szerint mindkét jelenség halmozottan érinti az etnikai csoportokat - hazánkban a romákat. Kutatásunkkal arra a kérdésre keressük a választ, hogy hazai városi környezetben a szegregált lét az érintettek számára milyen erőforrásokat hordoz, és miben korlátozza őket. Külön figyelmet szentelünk ezen erőforrások és korlátozó tényezők térbeliségének. Egy hazai város szegregátumaiban készült, kvalitatív primer adatfelvételen alapuló eredményeink rámutatnak arra, hogy a városi szegregátumok és környékük egyszerre hordozhatnak kulcsfontosságú erőforrásokat az ott élők számára és lehetetlenítik el a mélyszegénységből való kitörést. A kapcsolatok és erőforrások térbeli koncentrálódása következtében a meggondolatlan, területi dekoncentrációt (deszegregációt) előtérbe helyező antiszegregációs beavatkozások könnyen ronthatnak az érintettek helyzetén, és önmagukban semmi esetre sem adnak választ arra a komplex problémahalmazra, amivel az érintetteknek meg kell küzdeniük. Mivel az egyes szegregátumok is sokban különbözhetnek egymástól és a szegregátumok lakossága messze nem homogén, nem takarítható meg egyetlen antiszegregációs beavatkozás esetében sem a megfelelő feltárási-konzultációs folyamat, a

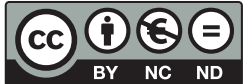


külső és belső kapcsolathálók feltérképezése, a személyre vagy családra szabott megoldások kidolgozása.

Janka TóTH: independent researcher; Tanya 849., H-6781 Domaszék, Hungary; tothjanka@gmail.com Boglárka MÉREINÉ BERKI: PhD student, Faculty of Economics and Business Administration Research Centre, University of Szeged; Kálvária sgt. 1., H-6722 Szeged, Hungary; mereine.berki.boglar@eco.u-szeged.hu

György MÁLOVICS: associate professor, Faculty of Economics and Business Administration Research Centre, University of Szeged; Kálvária sgt. 1., H-6722 Szeged, Hungary; malovics.gyorgy@eco.u-szeged.hu

Judit JUHÁSZ: PhD student, Doctoral School of Economics, Faculty of Economics, University of Szeged; Kálvária sgt.1., H-6722 Szeged, Hungary; judit.juhasz@eco.u-szeged.hu

Lajos BOROS: assistant professor, Department of Economic and Social Geography, University of Szeged; Egyetem u. 2., H-6722 Szeged, Hungary; borosl@geo.u-szeged.hu

KEYWORDS: urban segregation; spatially concentrated poverty; underclass; Roma; resources; antisegregation

ABSTRACT: Spatial segregation and spatially concentrated poverty are both serious issues in Hungarian cities and, according to previous studies, they heavily affect certain ethnic groups like, in the Hungarian context, the Roma people. The Roma are significantly overrepresented within the poor and marginalized population, they are "the poorest even among the poor".

Although spatial segregation and concentrated poverty, on the one hand, mean extreme disadvantages for the affected, they also carry resources. The aim of our research is to systematically reveal and understand what the resources' and limits' spatial concentration means for the extremely poor Roma living in the segregates (ghettos) of Hungarian cities making it the Hungarian urban underclass. We conducted qualitative interviews and participant observations in two Roma segregates of a major Hungarian city. Our open data collection and analysis allow to gain significant information about the perspectives of the urban underclass and analyze and evaluate it based on the existing literature.

Our results show that, on one hand, vital resources, like social connections and resources, concentrate within or close to the surrounding neighborhoods. On the other hand, the major limiting factors are also related to wider spatial scales, institutional structures and societal factors (e.g. attitudes and values). Therefore, anti-segregation policies and interventions focusing purely on deconcentration or desegregation of the marginalized Roma population are not enough to solve their complex problems. Even more, segregates can differ from each other in terms of resources and limits, and neither their population is homogenous. Therefore, besides the long term commitment and efforts of the majority society (including political decision-makers), it is also important to apply exploratory and consultation processes; to understand the inhabitants' internal and external systems of relationship; and to work out personalized or family-level solutions.

\section{Bevezetés}

A lakóhelyi szegregáció egyik formája a térben koncentrált szegénység; a szegények gyakran elkülönülve, egy adott övezetben, városrészben élnek. A koncentrált szegénységhez kapcsolódó fogalom az underclass, e csoport tagjait mély és tartósan átjárhatatlan szakadék választja el a társadalom többségétől. Hazánkban a polarizálódó társadalmon belül már a szegények és nagyon szegé- 
nyek között is egyre mélyebb a szakadék, és a szegénység egyre inkább integrációs problémává válik (Ladányi 2012). A szegénység, az etnicitás és a kirekesztés összefüggéseihez kapcsolódóan Emigh, Fodor és Szelényi (2001) hangsúlyozzák, hogy a romák egyre inkább az etnikai alapon definiált underclass csoportba kerülnek. Hazánkban a lakosság 3\%-a, megközelítőleg 300000 ember él szegregált lakóövezetben (telepszerü környezetben) (Domokos, Herczeg 2010) és legalább 1633 etnikai alapon is szerveződő szegregátum van. A koncentrált szegénység - az integrációs nehézségek, a korlátozott külső kapcsolatok és egyéb tényezők következtében - pedig komoly szerepet játszik a nyomor fenntartásában (Ladányi, Szelényi 2004; Massey, Condran, Denton 1987; Massey, Denton 1998).

Számos érv szólhat a szegregátumok felszámolása mellett (Ladányi 2009; Ladányi, Szelényi 2004; Pászka, Szűcs 2003). De a térbeli szegregáció nemcsak esélytelenséget jelent a társadalmi mobilitásra, hanem erőforrást, biztonságot is a szegregált közösség tagjai számára (Farkas 2012). Az elmúlt évtizedekben számos kutatás foglalkozott a települési szegregáció történeti gyökereivel, okaival, de kevés olyan elemzés látott napvilágot, amely az érintettek szemszögéből veszi számba azt, hogy a szegregált lét az érintettek számára milyen erőforrásokat jelent és miben korlátozza ôket. Jelen kutatásban e kérdésre keressük a választ egy hazai nagyváros szegregátumait vizsgálva, külön figyelmet szentelve ezen eróforrások és korlátozó tényezők térbeliségének.

Primer kutatásunkban résztvevői megfigyelésre és félig strukturált mélyinterjúkra támaszkodunk. Kutatásunk területi fókusza egy hazai megyei jogú város két roma szegregátuma. Tanulmányunkban először körüljárjuk a lakóhelyi szegregáció, a koncentrált szegénység, az underclass és gettó fogalmait, hazai kontextusba helyezve ezeket. Ezután bemutatjuk primer kutatási módszertanunkat, majd részletesen ismertetjük eredményeinket, reflektálva a kapcsolódó hazai szakirodalomra is. Végül az eredményekre alapozva levonjuk a hazai antiszegregációs programokhoz kapcsolódó következtetéseinket.

\section{Lakóhelyi szegregáció, koncentrált szegénység, underclass, gettók}

A lakóhelyi szegregáció a társadalmi egyenlőtlenségek térbeli távolságokként történő megjelenése. Ennek egyik formája a térben koncentrált szegénység: a szegények gyakran elkülönülve, egy adott lakónegyedben vagy övezetben koncentráltan élnek. ${ }^{1}$ Számos tanulmány próbálkozott a szegénységi koncentráció, valamint a szegénység jelensége közti kapcsolatrendszer feltárásával, azonban ez továbbra sem írható le egyszerü alapvetésekkel.

A koncentrált szegénység problémájának komplexitását tovább növeli, hogy ugyan a szegénység és koncentrált szegénység jelensége természetesen nem kizárólag etnikai jellegü, a probléma mégis halmozottan érint egyes etni- 
kai csoportokat. Hazánkban a cigány lakosság életszínvonala már az államszocializmus időszakában is alacsonyabb volt a többségi társadaloménál (Szoboszlai 2004). Napjainkban a szegénység megjelenése a hazai romák körében a nem romákéhoz képest majd tízszeres (Autonómia Alapítvány 2013). ${ }^{2}$ A 2000-es évek elején a cigány háztartások $82 \%$-a nem érte el a KSH által számított létminimumot, 56\%-uk a lakosság alsó jövedelmi tizedéhez tartozott (Kemény, Janky 2003). Ladányi (2012) szerint a semmilyen jövedelemmel nem rendelkezők aránya a magyarországi cigány népesség körében egyharmaddal magasabb, mint az átlagnépességben, azaz a romák felülreprezentáltak a szegény és kirekesztett népesség körében. Az etnikai diszkrimináció következtében a mélyszegény romák helyzete még a nem roma szegény csoportokéhoz képest is minősítetten nehéz (Havas 1999), a romák a szegények között is a legszegényebbek (Ladányi, Szelényi 2001).

A koncentrált szegénységhez kapcsolódó kategória az underclass. E társadalmi csoport főbb jellemzői (Ladányi, Szelényi 2004), hogy:

- térben elszigetelten, etnikailag szinte teljesen homogén gettókban élnek, amelyek még azon romák lakóhelyétől is elkülönülnek, akik gazdaságilag kicsit jobb helyzetben vannak;

- a többségi társadalom gyakran „kívülállónak”, „nemkívánatosnak”, „haszontalannak” tartja e csoportokat, mert „nem járulnak hozzá a társadalom fejlődéséhez”, hanem „segélyen, támogatáson élnek”;

- az underclass családok gyermekei jó eséllyel ugyancsak szegregált, mélyszegény körülmények közt élik le életüket - azaz körükben nagyon alacsony a társadalmi mobilitás szintje.

Az underclass esetében nem egyszerüen szegényégről és munkanélküliségről, hanem tartós szegénységről és tartós munkanélküliségről beszélhetünk, ami generációkon keresztül továbböröklődik és a térbeli elkülönüléssel fokozódik (Ladányi 2009, 2012). E csoport Magyarország népességének 7-8\%-át teszi ki, és ugyan nem követi pontosan az etnikai határokat, de mélysége és az elkülönülés merevsége etnikailag erősen determinált (Kemény, Janky, Lengyel 2004; Ladányi 2012).

Az underclass lét hazai kialakulását és fennmaradását többféle tényező magyarázza (Kozma 2003), ${ }^{3}$ amelyek kölcsönhatásban vannak egymással, újabb és újabb nehezítő körülményeket generálva, és amely körforgásból szinte lehetetlenné válik az önerőből való kilépés. E társadalmi csoportot mély és igen nehezen átjárható társadalmi szakadék választja el a társadalom többségétől, a szegények és nagyon szegények között egyre mélyebb szakadék tátong (Ladányi 2012). Stewart (2001) ugyanakkor felhívja a figyelmet arra, hogy a fogalomhoz kapcsolódó diskurzusokban gyakran megjelenik az az elképzelés, hogy az underclass egyben a szabályoktól való eltávolodást, aszociális viselkedést jelent, létrehozva a „szegénység kultúráját” az érdemtelen szegényekről szóló gondolatmenetekben. Meglátásunk szerint ezek a diskurzusok valóban aktívan részt vesznek a kirekesztettség és a dezintegráció megteremtésében és legitimációjá- 
ban, így fontosnak tartjuk tisztázni, hogy tanulmányunkban a Ladányi által meghatározott értelemben használjuk az underclass fogalmát. Ladányi János Szelényi Ivánnal egyetértésben azon az állásponton van, hogy az underclass kapcsán gyakran észlelt „aszociális” viselkedésmód alapvetően nem létrehozója annak, hanem alapvetően strukturális meghatározottságú és a strukturális feltételek megváltozásával módosulhat (Ladányi, Szelényi 2001). Ezt a megközelítést azért tartjuk fontosnak, mert felhívják a figyelmet a leghátrányosabb helyzetben lévők leszakadására és elszigeteltségére.

Az underclass által lakott, etnikailag homogén cigánytelepek sok szempontból megfeleltethetőek a gettó fogalmának. Wacquant (2004) szerint gettóról akkor beszélhetünk, ha az adott terület élesen elválik a település többi részétől, jól körülhatárolható; az itt élőket a többségi társadalom stigmákkal látja el; ők nem saját döntésük alapján, hanem valamiféle kényszer hatására költöztek ide; valamint a többségi társadalomtól elkülönülő, párhuzamos intézményrendszert használnak (Massey, Denton 1993). Wacquant (2008) azonban felhívja a figyelmet arra, hogy a gettó fogalma nem alkalmazható sémaszerűen a különböző kontextusokra - hiszen más folyamatok állnak az észak-amerikai, a nyugat-európai vagy éppen a kelet-közép-európai kirekesztés hátterében, illetve eltérő mértékủ a kisebbségek elszigeteltsége is (Kusmer 1997). Michael Stewart (2001) is ezen az állásponton van, és számos különbségre hívja fel a figyelmet a keleteurópai cigányok és az észak-amerikai feketék térbeli koncentrációjával és helyzetével kapcsolatban. Ugyanakkor abban egyetértünk más kutatókkal (Ladányi, Szelényi 2001; Váradi, Virág 2015), hogy a kelet-európai roma népesség szegregátumaiban a polarizációs folyamatok és az integráció nehézségei miatt kimutathatóak a gettó kialakulásának alapvető jegyei.

A gettók lehatárolása számos módszertani dilemmával jár. Valójában a helyi kontextus dönti el, hogy egy városrészt a helybéliek, vagy „szakértő" cigánytelepnek tekintenek-e (Lengyel 2006). Így a szegregátum - a helyi szereplők véleménye, érdekei mentén - folyamatosan változó konstrukció, mint ahogyan a gettók kialakulása sem pusztán spontán folyamatok, hanem a többségi társadalom beavatkozásainak, döntéseinek is az eredménye (Massey, Denton 1998). E dilemma feloldását az sem segíti, hogy a hazai közpolitika - az integrált városfejlesztési stratégiához kapcsolódóan - meghatározta a szegregátum fogalmát (NFGM 2012). Ez ugyanis szintén a különböző társadalmi szereplők nézőpontjait, érdekeit tükröző lehatárolási rendszer, azaz a tér társadalmi termelésének koncepcióját (Lefebvre 1991) követő konstrukció, amely merevségéből fakadóan nem képes figyelembe venni az egyedi sajátosságokat (Lennert, Kovács, Farkas, Bódi 2014; Váradi, Virág 2015).

A fenti dilemmák ellenére a szegregátum, gettó, cigánytelep stb. fogalmak mind a kutatásban, mind a politikában, mind pedig a helyi közbeszédben konkrét, valós helyekre, terekre vonatkoznak. Hazánkban a szegregációs folyamatok egyik iránya az alacsony státuszú, slumosodó városnegyedek gyors ütemű „elcigányosodása” (Pászka, Szűcs 2003). Jelen elemzés olyan városi szegregátu- 
mokra terjed ki, amelyeket mind a helyi többségi társadalom, mind pedig az ott lakó, magukat cigánynak valló lakosok „telep”-ként tartanak számon; a helyi antiszegregációs program „szegregátum”-ként azonosít, jellemzőikben megfelelnek a gettó, az itt lakók pedig az underclass kritériumainak.

A gettók, szegregátumok világa számtalan módon járul hozzá a szegénységi csapda fennmaradásához. A gettók „etnikai börtönök”, amelyek elzárják a stigmatizált népességet (Wacquant 2001). Nemcsak a társadalmi távolság eredményez fizikai szegregációt, hanem a fizikai szegregáció is társadalmi távolság kialakulásához vezet, az etnikai szegregáció rontja az érintettek relatív pozícióját a többséggel szemben (Massey, Condran, Denton 1987; Massey, Denton 1998). Ugyanakkor a térbeli szegregáció (és szegénységi koncentráció) az érintettek számára egyben erőforrás is lehet (Farkas 2012; Wacquant 2001). Így tehát a szegregáció egyszerre jelent erőforrást, biztonságot, valamint esélytelenséget a szegénységi csapda megtörésére.

A hazai települési szegregáció történeti gyökereivel, okaival, tendenciáival számos kutatás foglalkozott a közelmúltban (Boros 2008; Domokos, Herceg 2010; Kemény, Janky 2004; Kemény, Janky, Lengyel 2004; Ladányi, Virág 2009; Lennert, Kovács, Farkas, Bódi 2014; Siptár, Tésits 2014; Váradi, Virág 2015). Kevés olyan kutatás látott azonban napvilágot, amely strukturáltan tárja fel és elemzi, hogy a szegregált lét milyen erőforrásokat hordoz az érintettek számára, miben korlátozza őket, és mindez hogyan jelenik meg a hazai városi terekben. Csak az utóbbi években mutatott rá a hazai szegregátumokban élők kapcsolatrendszerének vizsgálata bizonyos folyamatokra (Durst 2002; Messing 2006). E tanulmányok - amellett, hogy hangsúlyozzák a szegregátumok esetében a megkötő kapcsolatok ${ }^{4}$ meglétét - arra is rávilágítanak, hogy a közösségek jelentős részében, elsősorban strukturális jellegü átalakulások (és átalakítások) következtében, e kapcsolatok folyamatosan gyengülnek, széttöredeznek. Azaz az egyszerủ deszegregáció - a koncentráció megszüntetése szétköltöztetéssel - az elkülönülés, csoportosulás pozitívumait is felszámolja. A szegregált környezetből való kikerülés az érintettek számára életük minden területét érintő alapvető változásokkal jár, így akár jólétük csökkenését, ellehetetlenülésüket és a szegregáció újratermelését eredményezheti. Több kutatás (Bolt, Phillips, van Kempen 2010; Bolt, van Kempen 2013; Bond, Sautkina, Kearns 2011; Kearns et al. 2013; Mugnano, Palvarini 2013) is rámutatott arra, hogy a szegregátumok felszámolása, a kevert népességű területek létrehozása nem oldja meg az elkülönülés problémáját, és az egymás mellett élők ugyanúgy párhuzamos társadalmakat hozhatnak létre. Ezáltal elvész a korábbi homogén közösségek összetartása, és összességében gyengül a társadalmi kohézió. Tehát a „mixing” közösségteremtő tevékenységek, „értelemmel bíró” interakciók nem hoznak valódi eredményt közösségi terek és események nélkül (Boros et al. 2016). Más hazai kutatások olyan példákat is felsorakoztatnak, amelyek tanulságai óva intenek attól, hogy ezek a közösségek, bár magasabb életszínvonalon, még inkább távol kerülhessenek a többségi társadalom tagjaitól, amivel véglegesen konzerválnák helyzetüket. Durst Judit (2010) egy olyan példát mutat be, ahol lakhatási 
és szociális integrációra elkülönített külső forrás felhasználásával a nem cigány (paraszt) lakosokkal együtt élő, de többségében cigányok lakta kistelepülés hogyan vált jóformán „cigányfaluvá” minden integrációs szándék és jóakarat ellenére. ${ }^{5}$ Ennek következtében maguk az itt élő romák is megszünni véltek minden kitörési útvonalat. A hídszerű kötések hiánya és a kényszerűségből kialakult párhuzamos életvilág az itt élő cigányok számára a társadalmi mobilitásnak gyakorlatilag minden esélyét megszüntette.

E problémák határozták meg jelen tanulmány fókuszát, kutatási kérdését és módszertanát.

\section{Kutatási célok, kontextus, módszertan}

Jelen kutatás fö kérdése, hogy a hazai városi szegregált, „underclass” lét milyen eröforrásokat jelent az érintettek számára és miben korlátozza óket, valamint, hogy hogyan alakul ezen eröforrások és korlátozó tényezók térbelisége.

E kérdések megválaszolásához egy hazai megyei jogú városban végeztünk adatgyűjtést. Városunkban két szegregátum található, amelyeket az integrált településfejlesztési stratégia (ITS) határolt le, és a helyi közbeszéd cigánytelepekként tart számon. A nagyobbikban körülbelül 250 fő él, ez a városközponttól sétálható távolságra (1,5 kilométerre), egy helyi bevásárlóközpont-jellegű terület, illetve piac szomszédságában található. A kisebbikben mintegy 120 ember él, ez a város peremén, a város legszélső, nem romák által lakott részétől is mintegy 500 méterre, a városközponttól 10 kilométerre fekszik.

A lakhatási viszonyok a legtöbbek számára mindkét szegregátumban nagyon szegényesek - magas a komfort nélküli lakások aránya, sokszor 5-7 fó él egyetlen, $20 \mathrm{~m}^{2}$ körüli szobában, a lakások rossz állapotban vannak. A kisebbik szegregátumban mindenki jogcím nélküli lakáshasználó, a szegregátum lakossága stabil, legtöbben évtizedek óta élnek ott, oda születtek, nem jellemző a beköltözés. A vonatkozó városi tervekben (a város antiszegregációs programjában) e szegregátum esetében a hivatalos cél nem a felszámolás, hanem az itt élők életminőségének javítása. Viszont a nagyobbik szegregátumot - a város tervei szerint - 2029-ig fokozatosan fel kell számolni. Az itt kiürülő lakásokat a helyi ingatlankezelő lakhatatlanná teszi, ám azokba újra és újra beköltöznek önkényes lakásfoglalók azaz az évtizedek óta ott élő családok mellé folyamatosan érkeznek új lakók is.

A két szegregátum tehát meglehetősen különböző. Eredményeinket emiatt összehasonlító jelleggel mutatjuk be, ami rálátást enged arra is, hogy mely elemek a szegregált lét általános velejárói, illetve az adott szegregátumhoz kapcsolódó specifikus tényezői.

Tanulmányunkban kétféle primer módszertanra támaszkodunk. Egy 2011 óta zajló részvételi akciókutatási (Pataki, Vári 2011) folyamat során (a szerzők közül hárman) résztvevői megfigyelést folytattunk. Megfigyeléseinkről terepmunka- 
naplót (Letenyei 2008) vezettünk. Emellett 25 félig strukturált egyéni mélyinterjút készítettünk a szegregátumokban élőkkel. Interjúinkban a kutatási kérdésünket indirekt módon közelítettük meg, ami rejtve maradt interjúalanyaink számára a teljes kutatási folyamat alatt. Így nem „húztuk rá” a saját előzetes „erőforrás és korlátozó tényező" értelmezésünket a kutatásra, hanem lehetőségünk nyílt az érintettek saját értelmezéseit megismerni, azaz feltárni és megérteni, hogy mi az, amit az érintettek erőforrásként és korlátozó tényezőként fogalmaznak meg.

$\mathrm{Az}$ „erőforrás” és „korlátozó tényező” fogalmakat a lehető legtágabban definiáltuk: minden olyan tényezőt ide soroltunk, amely az érintettek saját értelmezése és a mi megfigyeléseink szerint kapcsolatba hozhatók az érintettek jóllétével. Az elemzés első körében in vivo kódokat hoztunk létre - a mélyinterjúkban és kutatási naplókban egyaránt. Ezután ezekből kategóriákat alkottunk, és elemeztük a kódok és kategóriák egymáshoz való viszonyát is. Ilyen értelemben a grounded theory (Kucsera 2008) induktív, nyitott elemzési módszertanát vettük alapul, és ha elemzésünk nem is volt annyira nyitott, mint egy grounded theory elemzés, módszertanunk - annak jellegéből fakadóan - mindenképpen alkalmas az érintetti perspektíva feltárására, megértésére.

Az elemzés minőségbiztosítása érdekében minden egyes interjút legalább két elemző olvasta el, és jutott megegyezésre az erőforrásként értelmezhető kódokról, kategóriákról és ezek viszonyáról. Eltérő kódolás, kategorizálás és értelmezés esetén az elemzőknek egymással megegyezésre kellett jutniuk, és ahol ez nem sikerült, az adott szövegrész a végső elemzésbe nem került bele. Elemzésünket a tipikus pozíciókat, véleményeket kódoló idézetekkel színesítjük, amelyek - ha ennek ellenkezőjét nem jelezzük - a szegregátumban élő lakosoktól származnak.

Tehát az érintettek (szegregátumokban élők) jóllétét pozitívan és negatívan befolyásoló tényezők elemzésekor - mintegy endemikus perspektívát adva - az érintettek saját értelmezéséből indulunk ki. Ugyanakkor e percepciók - legitimitásukat nem megkérdőjelezve - külső, kutatói szemmel nézve nem minden esetben ellentmondásmentesek; ha azokat tágabb kontextusban is értelmezzük, kritikai értelmező keretbe foglaljuk. Ennek megfelelően, eredményeink bemutatásakor, ahol indokolt, az érintetti perspektívára külső, kutatói perspektívából, kritikai módon reflektálunk.

\section{A szegregátumok erőforrásainak és korlátozó tényezőinek térbelisége}

\section{A szegregátum mint erőforrás ${ }^{6}$}

A szegregátumhoz mint közeghez kapcsolódó erőforrások első csoportja - a szegregátumban élő romák értelmezésében - a helyi CNÖ és a köré szerveződő 
helyi szereplők fejlesztési beavatkozása. Tevékenységükhöz kapcsolódnak a telepeken élő romák számára szervezett rekreációs programok, közösségi házak és tanodák, a helyi középosztálybeli családokból álló támogató hálózat létrehozása, valamint az alkalmi jólléti támogatás (élelmiszercsomagok, ruhák, adminisztratív segítségek, tűzifa stb. adományok), mindezek nagyon fontosak az érintettek számára. Különbség alakult ki a két szegregátum között, e tevékenység jobban eléri a kisebbik szegregátumot, így ott e támogatás (és ennek fontossága) nagyobb, a városközeli szegregátumban viszont kevésbé jelent erőforrást az ott élőknek.

A szegregátum belső viszonyai is erőforrásként jelennek meg az érintettek szemében. A kisebb szegregátumban, amely a város számára megtartandó, a rendezetlen lakhatás ugyan probléma, hiszen emiatt nem lehet komfortosabbá tenni a lakásokat (pl. vizet, áramot bevezetni), ugyanakkor előnyöket is hordoz: olcsó lakhatást biztosít, azaz: ,azzal is jó nekünk, hogy nem kell fizetni. Mert ha fizetni kéne, akkor enni nem tudnánk."

A másik szegregátumban, amely hivatalosan is felszámolandó szegregátum, a helyi önkormányzat ennek megfelelően jár el: a bérlőknek időnként cserelakásokat, a tulajdonosoknak kivásárlást ajánl fel. Ugyanakkor e folyamatok átláthatatlan módon zajlanak, a döntéshozók az érintettekkel semmilyen konkrétumot nem közölnek a telep jövőjével kapcsolatban. Így mindenki bizonytalannak érzi lakhatási helyzetét, az olcsó lakhatás nem jelenik meg erőforrásként.

A kisebbik szegregátumban az ott élők értelmezésében az ő jóllétüket növelő tényező a szabad tér, a kertek, és ezek „szabad” módon történő használata. Ez egyfelől anyagi előnyöket jelent: kiskerti zöldség- és gyümölcstermesztési, illetve állattartási (malac, tyúk) lehetőséget: „Jó a saját veteményes, mert nem sok pénzünk van." De lehetőséget teremt alternatív jövedelemszerzésre is, ilyen például a „vasazás” (a vasak tárolása, a piac ingadozásainak kivédése). A nagyobb szegregátumban is tartanak egyesek állatokat, van kiskertjük, ám ez kevésbé gyakori. A lakók ezzel kapcsolatban inkább a nehézségekről beszélnek. És aki nem gazdálkodik, az is arról számol be, hogy „itt nem lehet normálisan gazdálkodni" - leginkább a rágcsálók jelenléte, illetve a termények (a magántulajdon) megvédésének nehézségei miatt.

Fontos erőforrást és egyszerre korlátozó tényezőt is jelentenek a lakók számára a közösség müködésének egyes aspektusai. A kisebbik szegregátumban az emberek „átjárkálnak egymáshoz”. A felnőttek „,szeretik a gyerekeket, az összeset”. Az emberek kiülnek a házuk elé, beszélgetnek, és „ez jó dolog”, „nem is bírnám a többiek nélkül”. A gyerekek mindig felnőtt és gyermektársaságban vannak a szegregátumban, az számukra olyan értelemben biztonságos hely, hogy oda ,idegenek” (akik nem a közösség tagjai vagy a közösség tagjai által jól ismert személyek) elvétve jönnek. A telep a gyerekeknek ,jó, mert egyben vannak és játszanak. Ők már ebbe születtek... Nekik nagy újdonság lenne, ha külön laknának, ha nem velünk kelnének, nem velünk feküdnének." 
A nagyobbik szegregátumban a barátságok, szomszédolás szintén jelen van és értéket jelent a lakók számára, ám itt a közösség töredezettebb. A nagy fluktuáció miatt a kapcsolatok nem az egész közösség, hanem annak egyes részeiben, leginkább rokoni kapcsolatok mentén szerveződnek: „A testvéremben, anyukámban, a páromban, meg az egyik sógorasszonyomban megbízok. A barátnőimmel csak beszélgetek, hárommal-néggyel." A telepi gyerekek itt is együtt vannak, házról házra járnak, együtt játszanak, esznek. A nagyobbak gyakran vigyáznak a kisebbekre, saját nyelvük van (ők madárnyelvnek hívják), amit a felnőttek nem értenek. Mindkét szegregátumra jellemző, hogy aki kiköltözött, az rendszeresen visszajár, mert „Ott jobb a társaság, van kivel beszélgetni, van kihez átmenned. Itt nincs. Hiányoznak nekem nagyon."

A telep tehát az ott élők szerint a lakók számára biztonságos, befogadó környezet, ahol nem kell a többség megítélésétől, diszkriminációtól tartani, mint például az integrált városi terek esetében. Itt az emberek kivétel nélkül a közösség teljes értékü tagjai, még akkor is, ha olyan helyzetben vannak (pl. értelmi sérültek), amely a többségi társadalomban önmagában is megnehezíti integrációjukat.

Ráadásul a telepen élők telepen kívüli kapcsolatai szinte kivétel nélkül gyengék, illetve bizonyos speciális esetekre, közösségekre korlátozódnak. Sokszor még a szegregátumból már kikerült, integráltabb környezetben élő romák is ,lenéznek minket”.

E telepi kapcsolatok egzisztenciális előnyöket is hordoznak: az emberek szükség esetén kisegítik egymást alapvető javakhoz, szükségletekhez való hozzájutásban. Segítik egymást élelmiszerekkel, a ház körüli munkákban (elromlott dolgok, háztartási eszközök javítása és megosztása; más jószágainak saját élelmiszerhulladék összegyűjtése), adminisztratív segítségek (hivatalos dolgok intézése) nyújtásával, közös szolgáltatásvásárlással (pl. TV, internet), átmeneti, kis összegű kölcsönökkel, vigyáznak egymás gyermekeire, elkísérik a gyerekeket az iskolába, ha valaki alkalmi munkát talált magának, és befogadják a fedél nélkül maradt rokonokat, barátokat.

A telep közösségét nagyfokú reciprocitás jellemzi: „Segítünk nekik. Ne adja Isten, ha én kérnék segítséget ilyenre valakitől, lehet, hogy megsajnálnának és adnának nekem is."

A szegregátumon belül a lakók üzletelnek is egymással: olcsón szállítanak egymásnak (fát, bútort), adnak internetet, töltenek le filmet, adnak el húst a maguk vágta állatból, vagy az általuk megvásárolt javakat (bicikli, telefon, tablet), adományokat olcsón továbbadják.

E „segítségek” és az „üzlet” speciális és ellentmondásos formája az uzsora. Ez egyrészt fontos erőforrásként jelenik meg, hiszen az itt élő emberek számára nem adott a legális kölcsönök lehetősége. Másrészt a magas kamatok és havi kamatfordulók miatt folyamatos anyagi teher, a szegénységi csapda egyik kulcstényezője.

A szegregátum segíti az érintetteket a munkavállalásban is. A telepen sokaknak a közmunka a belátható perspektíva, amit sok esetben a helyi CNÖ szervez, 
esetenként a munkavégzés helye is maga a szegregátum. Az ilyen típusú munkavégzés az érintettek szemében komoly erőforrás, hiszen sokszor ez a napi szintű túlélés záloga. Fontos azonban megjegyezni, hogy a közmunkaprogramok önmagukban tökéletesen alkalmatlanok mind a tisztes megélhetés biztosítására, mind a primer munkaerőpiaci integráció (és ezen keresztül a társadalmi mobilitás) elősegítésére. A primer munkaerőpiacon ugyanakkor jellemzően csak a nehéz (fizikai), átmeneti, rosszul fizetett és nem bejelentett munka jut számukra. Ezt gyakran a szegregátumból szervezi valaki, sokszor az érintettek szükségleteit figyelembe véve (pl. napi/heti fizetés, csoportos/együttes munkavégzés).

A szegregátum világa tehát kulcsfontosságú erőforrásokat hordoz az ott élők számára - az egyik helyi roma vezető szerint „ha csak úgy kiköltöztetjük a telepről az embereket, egymás nélkül elvesznek".

A hazai cigánytelepi léttel foglalkozó kutatások zöme - a romák kapcsolathálójának, megélhetési stratégiáinak vizsgálata - e részhez kapcsolódik. Albert és Dávid (2006) szerint a romák kapcsolati hálója, a megkötó társadalmi tóke alapvetően gazdagabb. Stewart (2001) szerint e kötések még a felfelé való mobilitásban is szerepet játszhatnak, ezt azonban más kutatások cáfolták (Durst 2002; Messing 2006; Messing, Molnár 2011a, 2011b). Az újabb hazai kutatások árnyalják a képet az erős megkötő társadalmi tőke jelenléte, illetve az ez által biztosított támogatás vonatkozásában. Solt (2010) szerint a szegregátumban az egymáshoz való viszonyt számtalan ellentétes irányú kötés alakítja, a hagyományos, reciprocitáson alapuló kapcsolatok felbomlóban vannak. A gyarapodást nem nézik jó szemmel, a lakók inkább csak a bajban segítik ki egymást, a legelesettebbek pedig ebből a védőhálóból is gyakran kiszorulnak. Durst (2002), Messing (2006), valamint Messing és Molnár (2011a, 2011b) szerint a legszegényebbek körében egyre gyakoribb az ún. „kapcsolatvákuum”: sem megkötö, sem áthidaló vagy összekapcsoló értelemben nincsenek valódi kötések. Mivel már nincs mit megosztani, a családok saját védelmük érdekében szeparálódnak. Heterogénebb közösségek esetén pedig, ahol bizonyos családok rendelkeznek áthidaló kapcsolatokkal, a kiemelkedők tudatosan igyekeznek megszakítani megkötő kötéseiket.

Azt, hogy a szegregátum egyszerre biztonságos, otthonos, erőforrásokat jelentő környezet, illetve egy hierarchikus, sokszor fragmentált és a tagok számára különböző típusú és mértékű előnyöket hordozó hely, azaz az „ellentétes irányú kötések" (Solt 2010) jelenlétét jelen kutatás megfigyelései is alátámasztják. E kötések negatív, „széthúzó” oldalával foglalkozik tanulmányunk következő része.

\section{A szegregátum világa mint „széthúzó” tényező}

A szegregátumban uralkodó lakhatási viszonyok és a lakókörnyezet állapota komoly problémát jelent az ott lakók számára. Az egyes házak körüli „gaz, dzsumbuj”, 
„kosz”, „szemét” vagy a WC-k hiánya. Már egy-két olyan háztartás, amely nem képes rendet tartani saját portája körül - megélhetési stratégiájuk (pl. lomozás), az alapvető infrastruktúra ( $\mathrm{pl}$. WC) hiánya vagy személyes problémáik (pl. szenvedélybetegségük) következtében - kihatással van az egész telep állapotára. A szegregátumokat a helyi politika „határon túli” (Harper, Steger, Filcak 2009) területként kezeli, azaz a legalapvetőbb közszolgáltatásokat sem biztosítja, így nem végez rendszeres, lakóegységenkénti szemétszállítást és nem takarítja a közterületet.

Egyik szegregátumban sincs az embereknek magánszférája olyan értelemben, mint ahogyan egy középosztálybeli közegben. Így a lakók nem tudják magukat pl. a szenvedélybetegben szenvedő szomszédoktól elszigetelni, és a saját tulajdon megvédése is nehézséget okoz. E problémáktól csak a legtehetősebb családok képesek magukat védeni, magánszférájukat megteremteni: „Amikor részeg volt, amikor ivott nagyon rossz szokásai voltak... Nem hagyott aludni se. Hajnal 2-3 órakor ezt csinálta, a gyerekeket se hagyta aludni. Nem bírtam már idegileg."

A szegregátumokon belül a magántulajdonhoz való viszony is eltér a többségi társadalomban (pl. a kutatók saját környezetében) tapasztaltaktól. Ha valakinek „több van”, a rokonok és barátok elvárják a segítséget. Ez erőteljesen összefügg a szélsőséges egyenlősdi jelenségével (Ladányi, Szelényi 2004), amely a reciprocitás kapcsán előny, de egyben nehézséget is jelent az érintetteknek.

Akárcsak általában a „közösségek” (MacQueen et al. 2001), az általunk megismert szegregátumok közösségei is egyfelől közös értékekkel, cselekvésekkel, ügyekkel és perspektívákkal jellemezhetők, másfelől viszont fragmentáltak, a tagoknak megvannak a közösségitől eltérő személyes érdekeik, konfliktusaik. A kisebbik szegregátum esetében a fragmentáltság és a konfliktusok elsősorban a családi viszonyokban jelentkeznek. Ennek negatív hatásait erősíti a belső telepi hierarchia, amelynek következményeként egyesek elnyomva érzik magukat az „erős emberek” által, „mert ő ilyen nagyravágyó, ki akar tűnni a cigányok közül, azt hiszi ő a király." A nagyobb szegregátumban élők szerint régen sokkal jobb volt ott élni. Azért, hogy ez megváltozott, elsősorban az újonnan beköltözőket okolják - különösen azt a beköltözési hullámot, amely egy korábbi elhibázott helyi szegregátumfelszámolás következtében jelent meg. Ennek kapcsán komoly konfliktus és fragmentáció (klikkesedés) van az önkényes lakásfoglalók és a jogcímmel rendelkező lakók között: „Akiknek van magántulajdonuk, meg bérelt joguk, tehát szó szerint az önkényeseket megölnék."

A szegregátumban az egyik legnagyobb probléma, hogy ott „nem lehet rendesen nevelni a gyereket” - a gyerekek eltanulják a „hülyeséget”, a „rosszat”, ami iskolai viselkedésüket is befolyásolja. Ahogyan azt a szakirodalom is megerősíti (Szilvási 2008), a területi szegregáció ilyen értelemben is sajátos környezetet teremt, amely hat a gyerekek világról kialakított képére, elvárásaira, normáira, és azt eredményezi, hogy a gyerekek számára csak korlátozott felnőttminták érhetőek el, csökkentve esélyeiket más életpályák elérésé- 
re. A nagyobbik, városközeli szegregátumban sokak legnagyobb problémája, hogy a szegregátum - egyesek szerint a városközeli fekvésből is fakadóan egyes lakóknak jó terepet ad bizonyos bűnözési formákra. Ezt a gyermekek nap mint nap látják, ilyen értelemben tehát nem a biztonság, hanem éppen annak teljes hiánya jellemzi a szegregátumot.

\section{Erőforrások a szegregátum közelében}

Az érintettek az alapvető javakat (élelmiszereket, ruhákat) olcsón, olcsó boltokban tudják csak beszerezni.

A városközpont ,jobb hely”, mint a város pereme, mert ott ezek könnyebben elérhetők. Fontos a városszéli szegregátum közelében havonta megrendezésre kerülő vásár, ahol a lakók java megjelenik. A városközeli szegregátum esetében e szerepet a (gyakran vásári jelleget öltő) közeli piac tölti be.

A szegregátumok közelében található intézményekben az érintettek az évek alatt személyes kapcsolatokra tettek szert. A városszéli szegregátum esetében ilyenek a közeli családsegítő iroda egyes munkatársai, egyes helyi rendőrök, a helyi iskola igazgatója és tanárai, a helyi boltosok - az élelmiszerboltostól a hentesen és turkálóson át a gyógyszertárosig -, az orvos.

A kisebbik szegregátum esetében kiemelkedik a szegregátumhoz közeli iskola szerepe, mert ez „közel van”, és a „gyerekek már megszokták, megszerették". Az összes telepi gyerek ide jár - együtt más helyi, nem telepi gyerekekkel -, a jelenlegi szülők közül is sokan itt tanultak. Az érintettek szemében biztonságot jelent a többi telepi gyerek jelenléte, az iskola működő viszonyt alakított ki a családokkal: „Úgy voltam vele, hogy azért íratom őket ide, mert a cigány gyerekek mind ide járnak. Ha magyarok közé íratom, nem illeszkedtek volna be. Mi már megszoktuk."

A nagyobbik szegregátumban is megjelennek hasonló vélemények a közeli oktatási intézményekkel - pl. az óvodával - kapcsolatban. Ugyanakkor ez a fajta biztonságérzet szélesebb perspektívából nézve meglehetősen ellentmondásos, amennyiben ez - akár iskolán belüli - szegregációs folyamatokkal (Fejes, Kelemen, Szűcs 2013) párosul (vagy ilyen folyamatokat erősít fel).

Segítséget jelentenek még a szegregátum körüli személyes családi-ismerősi kapcsolatok, ahol támogatásként vagy munka fejében kaphatnak az érintettek élelmiszert, bútorokat vagy tüzifát.

A szegregátumok elhelyezkedése fontos az érintettek számára abból a szempontból is, hogy az mennyire teszi lehetővé az alapvető szükségletek kielégítéséhez szükséges alternatív erőforrás-beszerzési módokat. Tipikusan ilyenek a már említett lomozás, (aminek folytatásához fontos, hogy legyen tér tárolni, értékesíteni a megszerzett dolgokat), a kukázás, illetve a tüzelőanyag-gyüjtés. A szegregátumban élő családoknak a tél anyagilag különösen megterhelő, hiszen „vagy eszünk, vagy fütünk”. 
A szegregátum közelében megtalálható erőforrások túlmutatnak a szakirodalom által már feltárt összekapcsoló társadalmi tőke kategóriáján (Messing 2006), amely az intézményekkel és azok képviselőivel (pl. családsegítő intézményekkel) tudatosan létrehozott társadalmi tőke. A szegregátum közelében ennél sokkal spontánabb módon jönnek létre azon kapcsolatok, amelyek az érintetteknek erőforrást jelentenek, illetve maga a szegregátum környékének mint helynek vagy területnek a jellemzői is megjelenhetnek erőforrásként. Erre kiváló példa, hogy a nagyobbik szegregátumban bútoraikat többen a „bútorszállítóktól" szerzik: egyes vállalkozók a szegregátumban élőknek adják oda azokat a bútorokat, amelyeket nem tudnak máshogyan hasznosítani.

\section{Mert a többségi társadalom kizár?}

Kutatásunk az érintettek szélesebb környezetében, közegében elsősorban „kizáró” tényezóket tárt fel. Az elöítéleteket az érintettek életük minden területén megtapasztalják: munkában, iskolában, hivatalokban, a rendőrség vagy az egészségügy részéről, de általában is, az integrált, vagy akár virtuális terekben: „nem ismernek, de úgy elítélnek. Azért mert a bőrünk cigány."

A diszkrimináció és a mélyszegénység az élet minden területét meghatározza. A telepen élőknek esélyük sincsen kiköltözni onnan, szegénységük és cigányságuk miatt mások „lenézik” őket, a többségi társadalmi intézmények e problémákkal kapcsolatban nem segítenek. Az önkényes lakásfoglalók legális lakhatás hiányában elesnek sok olyan lehetőségtől (a helyi szociális juttatásoktól a társadalombiztosításon át a gyermekek ingyenes iskolai étkeztetéséig), amelyek segítségükre lehetnének szegénységük minimális enyhítésében.

Sok érintettnek arra sincs esélye, hogy integrált városi terekben mozogjon. Elérhetetlenek a „fizetős” integratív terek - a középosztály által használt kávézók, cukrászdák, mozi -, így a szegregátumon kívüli rekreációs terek sokszor egy-egy játszótérre, bisztróra korlátozódnak. Sokan nem képesek részt venni az ingyenes központi városi ünnepi-szabadidős eseményeken sem, egyrészt a közlekedési költségek miatt, másrészt mert „a gyerek mindent akar ott, és semmire nincs pénz". A városközeli szegregátumból vannak, akik e rendezvényeket látogatják - erre azért képesek, mert ezek gyalog, biciklivel, esetleg villamossal (aminek kapcsán többen számoltak be „lógásról”) elérhetők. A többségi szokások (pl. karácsonyi, születésnapi ajándék vásárlása a gyerekeknek - a középosztályhoz hasonló módon) is gyakran elérhetetlenek a szegregátumban élők számára. Így a szegregátumban élők nem képesek magukat a helyi közösség teljes értékü, egyenrangú tagjának érezni, nem képesek integrált terekben szégyenérzet nélkül megjelenni (Sen 1999). A szegregátum marad az a hely, ahol az érintettek otthon érezhetik magukat.

A gyerekeknek az iskolai évek alatt vannak integrált kapcsolataik, de felnőttkorukra az erős kapcsolatok mind a telepről vagy annak környékéről szár- 
maznak. Kivételt ez alól az egyes vallási felekezetekkel és tagjaikkal, valamint egy helyi középosztálybeli támogató hálózattal való kapcsolatok jelentik. Ez pedig azt jelenti, hogy szinte teljesen hiányzik helyben az áthidaló társadalmi tóke.

A többségi társadalom irányából érkező kizáró nyomások kapcsán két intézmény szerepe kulcsfontosságú. Az iskoláról a szülők tapasztalatai teljes összhangban vannak a hazai szakirodalom megállapításaival (Fejes, Kelemen, Szűcs 2013; Szilvási 2008): vagyis az iskola alkalmatlan a gyermekek hátrányának kompenzálására, integrációs szerepének betöltésére, sőt, felerősíti a társadalmi különbségeket. Hiába gondolják úgy az érintettek, hogy az iskola kulcsfontosságú lenne a szegénységi csapdából való kitöréshez, a gyakorlatban sok család nem képes gyermekeinek e téren megfelelő támogatást adni, az iskola pedig képtelen elősegíteni a társadalmi mobilizációt a szegregátumban élő romák számára.

Egyes szülők kifogásolják, hogy már a felvételinél érvényesül az oktatási intézmények szelekciója a telepi gyerekek hátrányára - ez hazánkban az oktatási szegregáció legerőteljesebb formája (Fejes, Kelemen, Szűcs 2013). Ugyanakkor az érintettek - szintén összhangban a vonatkozó szakirodalmi megállapításokkal (Fejes, Lencse, Szücs 2016) - hangsúlyozzák, hogy az iskolai deszegregáció önmagában nem oldja meg az iskolai integráció kérdését. Szülői tapasztalat, hogy a gyerekek az új, ,integrált” iskolában „nem találják a helyüket”, „,kiközösítik őket” és „nem képesek felvenni a tempót”.

Az iskola mobilizációs képességének teljes hiányát jól mutatja az az általános jelenség, hogy a telepi gyerekek nem vesznek részt a fizetős iskolai programokban - pl. kulturális programokban, kirándulásokon - és hogy szegénységük (pl. szegényes ruházatuk) miatt már az iskolában kiközösítik őket: a szégyenérzet nélküli megjelenés esélye sokaknak itt sem adatik meg. Az iskola mint intézmény nem érzékeny tehát a gyerekek szociális és etnikai hátterére, a legalapvetőbb szinten sem, így a telepi gyerekeknek sokszor a befogadás helyett a kiközösítés terévé válik: „Mikor láttam a többieket, hogy jönnek iskolába, mindig elment a kedvem és szégyenkeztem. Nem volt megfelelő ruhám. Amikor ők mentek boltba, én mindig hátramaradtam, mert nem tudtam bemenni, nem volt pénzem semmi."

A másik „kizáró” intézmény a helyi önkormányzat és annak ingatlankezelő vállalata. A rendszerváltás után kialakult új helyzetben (Harper, Steger, Filcak 2009) a városszéli szegregátumban található lakások használatában a lakók számára megfizethetetlen mértékủ (akár milliós nagyságrendű) tartozások gyűltek fel, ami leginkább a romákat érintette. Ekkor kezdtek el a szegregátum lakói adósságokat felhalmozni és váltak jogcím nélküli lakáshasználóvá. E helyzet rendezésében a helyi önkormányzat és ingatlankezelő nem partner, és ez lehetetlenné teszi az ingatlanok komfortosabbá tételét (víz, villany stb. bevezetését) is.

A városközeli szegregátumból - a felszámolással kapcsolatos városi szándék, az ezzel kapcsolatos szóbeszéd, valamint a városi kommunikáció és átlát- 
hatóság teljes hiánya, és ennek eredményeképpen fennálló bizonytalanság következtében - már azok is el akarnak menni, akik amúgy elmondásuk szerint jól érzik itt magukat. Az önkormányzat és az ingatlankezelő a szegregátumban lakó bérlőknek nem végez felújítást és nem ajánl fel megfelelő cserelakást a kiköltözni szándékozóknak. A magántulajdonosoknak - ahhoz az összeghez képest, amelyért ők a város integráltabb részein lakáshoz tudnának jutni - csak a töredékét ajánlja fel. Egyes érintettek szerint a városi önkormányzat és ingatlankezelő korrupt, rendszeresen kilakoltat olyan családokat, akik rendbe hozták maguk számára a korábban önkényesen elfoglalt ingatlant. Ráadásul ezután az ingatlankezelő lakhatatlanná teszi az üressé vált ingatlanokat, úgy jelenítve meg e rombolást a helyi közvélemény előtt, mintha ezt a szegregátum lakói okozták volna, amivel csak tovább fokozzák a helyi elő́téleteket.

Az állandó lakhatási bizonytalanság és kiszámíthatatlanság a közösség kohézióján is lenyomatot hagyott. A szegregátum felszámolásának terve állandóan ott „lóg a levegőben”. A lakók így megkötő kapcsolataikat (főleg abban az esetben, amikor ezt a szomszédság jelenti) már csupán ideiglenesnek tekintik, emiatt ezek a kapcsolatok széttöredeznek vagy egy-egy családra korlátozódnak. Az áthidaló és összekapcsoló kapcsolatok híján sok családnál a teljes társadalmi kirekesztődés veszélye fokozott mértékben fenyeget.

A kulcsfontosságú intézmények, illetve a többségi társadalom kapcsán tehát az érintettek alapvető élménye a magárahagyatottság, kirekesztettség. Hiába a néhány jó szándékú intézményi és intézményen kívüli szövetséges, ez a „magyarokkal” kapcsolatos általános - és a szakirodalom szerint is sok szempontból megalapozott - percepción nem változtat.

\section{Erőforrások és térhasználat}

Az eddig leírtak befolyásolják a szegregátumban élők térhasználati mintázatait is. A városszéli szegregátumban élők a szegregátumban és annak közelében közlekednek napi rendszerességgel, a városközpontba ritkán járnak be, jellemzően bevásárlás, „papírok” (hivatali ügyintézés) vagy orvos miatt. Ennek anyagi okai is vannak, a városközpontba busszal oda-vissza sokba kerül a családok jövedelméhez képest: „Biciklivel közlekedek, csak az most jelenleg nincsen. Bérletem, se buszjegyem nincsen, így rá szoktam menni a buszra, bérlet nélkül, minden nélkül, muszáj."

A közösségből csak a középiskolás gyerekek járnak rendszeresen a városba. A település közigazgatási határait a családok elvétve hagyják el, elsősorban rokoni kapcsolatokhoz füződő események miatt.

A szegregátumban, illetve környékén elérhető erőforrások (1. táblázat) fontosságát mutatja, hogy aki kiköltözne a telepről, az - a városszéli szegregá- 
1. táblázat: Erőforrások és korlátozó tényezők a városi szegregátumokban élő romák számára Resources and limiting factors for Roma people living in urban segregates

\begin{tabular}{|c|c|c|}
\hline Tényezö & Nagyobb szegregátum & Kisebb szegregátum \\
\hline \multicolumn{3}{|l|}{ A szegregátumok föbb jellemzői } \\
\hline Távolság a városközponttól & A városhoz közel & A várostól távol \\
\hline Lakosság & $\begin{array}{l}\text { A lakosok egy része } \\
\text { hosszabb távon ott } \\
\text { lakik, másik részük } \\
\text { rendszeresen } \\
\text { cserélődik }\end{array}$ & Állandó lakók \\
\hline \multicolumn{3}{|l|}{ A szegregátumon belüli erőforrások } \\
\hline $\begin{array}{l}\text { A CNÖ-n keresztül a telepieknek érkező szociális } \\
\text { juttatások }\end{array}$ & Részben & Erőteljesen \\
\hline $\begin{array}{l}\text { A rendezetlen lakhatási viszonyok miatti olcsó } \\
\text { lakhatás }\end{array}$ & Nem említik & Erőteljesen \\
\hline $\begin{array}{l}\text { Meglevő szabad tér, kertek és ezek viszonylag } \\
\text { szabad használata }\end{array}$ & Nem említik & Erőteljesen \\
\hline $\begin{array}{l}\text { Közösség, közösségi élet, emberi kapcsolatok, } \\
\text { hangulat, szomszédolás, szeretet, gyerekeknek } \\
\text { közösség, befogadó, biztonságos barátságos közeg } \\
\text { - összekötő társadalmi tőke }\end{array}$ & $\begin{array}{l}\text { Erőteljesen, bár mivel } \\
\text { a közösség } \\
\text { fragmentáltabb, ezért } \\
\text { sokszor a } \\
\text { részközösségek } \\
\text { szintjén jelenik meg }\end{array}$ & Erőteljesen \\
\hline $\begin{array}{l}\text { A szegregátum közössége által biztosított } \\
\text { egzisztenciális előnyök - segítség, támogatás, } \\
\text { megosztás, reciprocitás }\end{array}$ & Erőteljesen & Erőteljesen \\
\hline A szegregátumokban rejlő üzleti lehetőségek & Megjelenik & Megjelenik \\
\hline $\begin{array}{l}\text { Munkavállalás (közmunka, telepen szervezett } \\
\text { munka) }\end{array}$ & Megjelenik & Erőteljesen \\
\hline \multicolumn{3}{|l|}{ A szegregátum mint széthúzó tényező } \\
\hline $\begin{array}{l}\text { Telepi lakhatási viszonyok, a telep mint } \\
\text { lakókörnyezet állapota }\end{array}$ & Erőteljesen & Erőteljesen \\
\hline $\begin{array}{l}\text { A magánszféra hiánya, közösségen belüli } \\
\text { elszigetelődés lehetetlensége (pl. szenvedélybeteg } \\
\text { tagoktól, bűnözéstől) }\end{array}$ & Erőteljesen & Erőteljesen \\
\hline $\begin{array}{l}\text { Magántulajdon, segítséggel kapcsolatos elvárások, } \\
\text { a szélsőséges egyenlősdi negatív hatása }\end{array}$ & Megjelenik & Megjelenik \\
\hline $\begin{array}{l}\text { A közösség fragmentáltsága, konfliktusok, } \\
\text { közösségen belüli hierarchia }\end{array}$ & Erőteljesen & Erőteljesen \\
\hline $\begin{array}{l}\text { A szegregátumban nem lehet normálisan } \\
\text { gyermeket nevelni }\end{array}$ & Erőteljesen & Erőteljesen \\
\hline
\end{tabular}




\begin{tabular}{|c|c|c|}
\hline \multicolumn{3}{|l|}{ Erőforrások a szegregátum közelében } \\
\hline Olcsó bolt, piac, vásár & Erőteljesen & Erőteljesen \\
\hline Intézményi személyes kapcsolatok & Megjelenik & Erőteljesen \\
\hline Bizalom a közeli, megszokott oktatási & Megjelenik & Erőteljesen \\
\hline \multicolumn{3}{|c|}{ intézményekben, ahová a többi telepi gyerek is jár } \\
\hline Személyes családi-ismerősi kapcsolatok & Megjelenik & Megjelenik \\
\hline $\begin{array}{l}\text { Alternatív erőforrásbeszerzési módok (lomozás, } \\
\text { tűzifa, kukázás) }\end{array}$ & Megjelenik & Megjelenik \\
\hline \multicolumn{3}{|l|}{ Kizáró tényezők a szélesebb struktúrákból } \\
\hline $\begin{array}{l}\text { Előítéletek és szegénység mint korlátozó tényezők } \\
\text { az élet minden területén }\end{array}$ & Erőteljesen & Erőteljesen \\
\hline $\begin{array}{l}\text { Az integrált terek használatának, a „közösség } \\
\text { teljes értékű tagja vagyok” érzésnek a hiánya }\end{array}$ & Erőteljesen & Eröteljesen \\
\hline Az áthidaló társadalmi tőke hiánya & Erőteljesen & Erőteljesen \\
\hline Iskola & Erőteljesen & Erőteljesen \\
\hline Helyi ingatlankezelő & Erőteljesen & Erőteljesen \\
\hline $\begin{array}{l}\text { Munkalehetőségek (a munka hiánya, nehéz, } \\
\text { alkalmi, rosszul fizetett munkák, közmunka) }\end{array}$ & Erőteljesen & Erőteljesen \\
\hline
\end{tabular}

tum esetében - leginkább „helybe”, „a közelbe” költözne. Az erőforrások és kapcsolatok (különösen az iskola) mellett ebben szerepet játszik, hogy „Itt megszoktam, a város túl nagy, nem úgy ismerem, mint a környéket", további szempont a lakhatás olcsósága, valamint a tér, a kert fontossága: „Laknék itt a közelben, de egy jó helyen. Kertes házba költöznének, olcsóba. Ellennék, lefoglalnám magamat."

Az érintettek, különösen a nők nehezen megoldhatónak vagy egyenesen megoldhatatlannak tartják, hogy családi teendőik mellett akár a város másik szélén vállaljanak munkát. „Amikor azt mondják, családos asszonynak lenne munka, akkor menjen máshova, más városba messzire. Olyan nem lehet. Nem létezik... és akkor van egy kiskorú meg egy másik gyereke. Az is kiskorú. Vidd el időben iskolába, vidd el óvodába időpontra. Aztán még érjen be? Hajnali 6-ra. Ez lehetetlen."

A város közeli szegregátumból sokan csak a boltig mennek el rendszeresen „ide a közelbe”, és nem járnak más városokba. A költözés kapcsán fontosak a meglévő kapcsolatok, legtöbben csak a városon belül költöznének.

A kapcsolatok és erőforrások helyi, kis léptékủ koncentrálódása, a szegregátum és környéke mint ismert és biztonságos hely, valamint a szegénység és diszkrimináció azt eredményezik, hogy a szegregátumban lakók erősen kötődnek a szegregátumhoz és annak környékéhez, távolabbi helyek megismerésétől tartanak. Ilyen értelemben térperspektívájuk jóval szűkebb a helyi középosztálybeliekéhez képest. 


\section{Az általános megállapítások mögötti sokféleség}

A szegregátumban élők nagyban különböznek egymástól vágyaikat, problémáikat, mentális állapotukat, családi helyzetüket, iskolai végzettségüket, munkaerőpiaci esélyeiket, erőforrásaikat illetően. Egyesek számára a szegregátumból való kiköltözés is megjelenik a családi tervekben, a gyerekek szakmát szereznek vagy úton vannak e felé, esélyt adva a családnak a jövőbeli térbeli és társadalmi mobilitásra. Másoknak viszont a szegregátum világa és annak környéke jelenti azt a - sok esetben lyukakból szőtt (Messing 2006) - védőhálót, amely segít a legalapvetőbb javakhoz való hozzáféréshez. Az önkényes lakásfoglaló családok például még az underclasson belül is a legsérülékenyebb csoportnak tekinthetők.

\section{Következtetések: adalékok a hazai városi antiszegregációhoz}

Kutatási eredményeink alapján több olyan következtetést is levonhatunk, amelyek releváns szempontokat nyújthatnak a hazai városi antiszegregációs törekvésekhez.

A szegregátum és környéke kulcsfontosságú erőforrásokat hordoz az ott élők számára. A szegregátum a városon belül az otthon, a biztonság, a családi és baráti kapcsolatok elsődleges tere, amely egzisztenciális szempontból is alapvető fontosságú. Ez nem azt jelenti, hogy a szegregált helyzeteket fenn kellene tartani, hiszen az előnyökkel a szegregátum világa egyszersmind ellehetetleníti a „normális életet és gyermeknevelést”, az anyagi javak minimális mértékủ felhalmozásának képességét. Az érintettek többsége maga mögött hagyná a szegregátumot, amire azonban képtelen, mivel a lakóhelyi szegregáció hatása az érintettek jóllétére strukturális, nem pedig egyéni, így annak megváltoztatása túlmutat az egyének képességein és korlátozza az érintettek életesélyeit - egyéni utaktól, motivációktól, személyes teljesítményektől függetlenül (Massey, Denton 1998).

A kapcsolatok és erőforrások térbeli koncentrálódása azonban jelzi: a meggondolatlan antiszegregációs beavatkozások könnyen ronthatnak az érintettek helyzetén, hiszen a területi dekoncentráció (deszegregáció) egyrészt komoly erőforrásokat vehet el az érintettektől, másrészt önmagában nem válasz arra a komplex kihíváshalmazra, amellyel az érintetteknek szembe kell nézniük. Különösen azért, mert míg az erőforrások a szegregátumban és annak közelében koncentrálódnak, addig a szegreátumok lakosságát érő - a városi underclass helyzetének tehetetlenségét fenntartó - kizáró hatások gyakran a szegregátumoknál lényegesen nagyobb térbeli és intézményi léptékhez (iskolához, munkaerőpiaci folyamatokhoz), szélesebb társadalmi értékekhez, normákhoz (diszkrimináció) kötődnek. A nemzetközi tapasztalatokhoz hasonlóan (Wacquant 
2001) az etnikai alapú diszkrimináció és szegregáció messze túlmutat a szegregátumok világán, megjelenik az iskolákban, közösségi helyeken, munkaerőpiacon. Az antiszegregáció így önmagában nem szünteti meg a kirekesztést, sőt, a szegregáció, a koncentrált szegénység újratermelődéséhez vezethet. A hatékony antiszegregációs folyamatnak a fenti hatások ellensúlyozásával is foglalkoznia kell.

A helyzetet tovább bonyolítja, hogy a szegregációt okozó és fenntartó tényezők csak lassan változtathatók (változnak), és a szegregátumok lakossága nem homogén. Míg egyes családok feltehetően viszonylag gyorsan megtalálnák a helyüket integráltabb környezetben, vannak, akiknek szinte minden erőforrásuk a szegregátumon belül és annak környékén koncentrálódik. Az ő esetükben a szegregátum fölszámolása végzetes lehet. Mindez egybecseng azokkal a külföldi tapasztalatokkal (pl. Bolt, Phillips, van Kempen 2010; Bond, Sautkina, Kearns 2011; Mugnano, Palvarini 2013), amelyek a kevert lakosságú városrészek létrehozásával kapcsolatosak. Már csak e sokféleség miatt sem takarítható meg - egyetlen antiszegregációs beavatkozás esetében sem - a megfelelő feltárási-konzultációs folyamat, az egyes élettörténetek, személyes lehetőségek megismerése, a külső és belső kapcsolathálók feltérképezése, a személyre vagy családra szabott megoldások kidolgozása. Az erőforrások és kapcsolatok milyensége, fontossága és térbeli koncentrációja szegregátumról szegregátumra változhat - ahogyan ezt kutatásunk már két, azonos településen található szegregátum esetében is kimutatta. Ez tovább növeli az antiszegregációs beavatkozások kockázatait, valamint hangsúlyozza a megvalósítandó együttműködés és konzultáció fontosságát.

\section{Jegyzetek}

1 A szegénység fogalmának (pl. szubjektív-objektív, abszolút-relatív, jövedelmi-többdimenziós), valamint mérésének (pl. egydimenziós, többdimenziós) több megközelítése létezik, azonban ezek részletes bemutatása túlmutat jelen tanulmány keretein. Az általunk vizsgált közösségek (telepeken, szegregált körülmények között élő romák) rendszerint minden definíció szerint szegénynek minősülnek.

2 Azt, hogy kit tekintünk „cigánynak”, számos szerző boncolgatta már (Kemény, Janky 2003; Kemény, Janky, Lengyel 2004; Ladányi 2009, 2012; Ladányi, Szelényi 2001; Szuhay 1999). A kérdés tudományos igényű meghatározásának, nehézségeinek (lehetetlenségének) részletes bemutatása túlmutat jelen tanulmány keretein.

3 Az underclass kialakulásával és fennmaradásával kapcsolatos vita érdemi bemutatása messze túlmutat tanulmányunk keretein, itt csak annyit jelzünk: e vitában a Ladányi-Szelényi szerzőpáros véleményével összhangban azt az álláspontot képviseljük, miszerint a strukturális és viselkedési jellegű előnyök és hátrányok bonyolult kölcsönhatásában a strukturális oldal a meghatározóbb, a potenciálisan szintén létező viselkedésbeli jellegzetességek alapvetően strukturális meghatározottságúak (Ladányi, Szelényi 2001).

4 Többfajta kapcsolatot, társadalmi tőketípust különböztet meg a kapcsolódó szakirodalom (Messing 2006; Putnam 1993; Woolcock, Narayan 2000). A megkötő társadalmi tőke (bonding 
social capital) zárt etnikai vagy családi kapcsolatok révén jön létre és bizalmon, szolidaritáson, reciprocitáson alapul. Előnyei mellett zártsága miatt a társadalmi mobilitás korlátjaként is jelentkezhet. A társadalmi mobilitást elsősorban a társadalmi csoportokon átnyúló kötések segíthetik elő: az áthidaló társadalmi tőke (bridging social capital) segít hozzáférni más csoportok erőforrásaihoz, az összekapcsoló társadalmi tőke (linking social capital) pedig civil és állami szervezetekhez, intézményekhez, és más hierarchikusan elkülönülő társadalmi egységekhez kötődő kapcsolatokat jelent. A megkötő társadalmi tőke amellett, hogy komoly erőforrást jelenthet, képes hátráltatni ez utóbbi két tőketípus kibontakozását.

5 A telepfelszámolás során az ott élő romák lakhatási lehetőségeinek javítása érdekében az önkormányzat piaci ár fölött felvásárolta a település központjában található, nem cigányok lakta házakat, így bár a cigánytelepen élő romák komfortosabb lakásokba kerülhettek úgy, hogy a „félszocpol” jellegü támogatást kiterjesztették használt lakásokra is, melyeket az önkormányzat értékesített nekik, ám ezzel egyidejűleg a településen élő nem cigány lakosság kiköltözött.

6 Elemzésünket azon tényezők bemutatásával kezdjük, amelyeket az érintettek erőforrásként (azaz jóllétüket növelő tényezőként) említettek. Fontosnak tartjuk elöljáróban is hangsúlyozni, hogy az erőforrás vagy korlátozó tényező, valamint a jóllétet pozitívan vagy negatívan befolyásoló tényező felosztás az érintett szegregátumokban annyiban mindenképpen mesterséges, hogy ugyanazon tényezők egyszerre jelennek meg erőforrásként és korlátozó tényezőként az érintettek számára.

\section{Irodalom}

Albert F., Dávid B. (2006): A kapcsolati tőke dimenziói etnikai metszetben. In: Kolosi T., Tóth I. Gy., Vukovich Gy. (szerk.): Társadalmi riport. Tárki, Budapest, 351-372.

Autonómia Alapítvány (2013): A mélyszegénységben élók helyzete Magyarország legszegényebb kistérségeiben. Kutatási beszámoló. Autonómia Alapítvány, Budapest

Bolt, G., Phillips, D., van Kempen, R. (2010): Housing policy, (de)segregation and social mixing: An international perspective, Housing Studies, 2., 129-135. http://doi.org/fhxtx2

Bolt, G., van Kempen, R. (2013): Neighbourhood based policies in the Netherlands: counteracting neighbourhood effects? In: Manley, D., van Ham, M., Bailey, N., Simpson, L., Maclennan, D. (eds.): Neighbourhood effects or neighbourhood based problems? Springer, Dordrecht, 195-213. http://doi.org/cbtg

Bond, L., E., Sautkina, E., Kearns, A. (2011): Mixed messages about mixed tenure: do reviews tell the real story? Housing Studies, 1., 69-94. http://doi.org/fb47vp

Boros L. (2008): A város depriváció térbelisége - konfliktuselméleti megközelités szegedi esettanulmányokkal. PhD disszertáció. Szegedi Tudományegyetem, Szeged

Boros, L., Fabula, Sz., Horváth, D., Kovács, Z. (2016): Urban diversity and the production of public space in Budapest. Hungarian Geographical Bulletin, 3., 209-224. http://doi.org/cbth

Domokos V., Herczeg B. (2010): Terra Incognita: magyarországi szegény- és cigánytelepek felmérése - első eredmények. Szociológiai Szemle, 3., 82-99.

Durst J. (2002): „Innen az ember jobb, hogyha meg is szabadul.” Megélhetési stratégiák egy kisfalusi cigány közösségben. Esély, 4., 99-121.

Durst J. (2010): „Minden évben máshogy fordul a világ.” A telepfelszámolástól a szegregált cigány faluig. AnBlokk, 4., 34-38.

Emigh, R. J., Fodor, É., Szelényi, I. (2001): The racialization and feminization of poverty? In: Emigh, R. J., Szelényi, I. (eds.): Poverty, ethnicity, and gender in Eastern Europe during the market transition. Praeger Publishers, Westport, 1-32.

Farkas Zs. (2012): Hidak és sorompók. A telepfelszámolásban, a településeken végzett terepmunka tapasztalatai és integrációs hatásai. Társadalmi Együttélés, 4., 1-21. 
Fejes J. B., Kelemen V., Szűcs N. (2013): Szülők mentorálása a hátrányos helyzet átörökitésének megelőzése érdekében. SZTE JGYPK, Szeged

Fejes J. B., Lencse M., Szűcs N. (szerk.) (2016): Mire jó a tanoda? A Tanoda Platform keretében összegyüjtött innovációk, kutatások, történetek. Motiváció Oktatási Egyesület, Szeged

Harper, K., Steger, T., Filcak, R. (2009): Environmental justice and roma communities in Central and Eastern Europe. Environmental Policy and Governance, 4., 251-268. http://doi.org/cd44jr

Havas G. (1999): A kistelepülések és a romák. In: Glatz F. (szerk.): A cigányok Magyarországon, MTA, Budapest, 163-204.

Kearns, A., McKee, M. J., Sautkina, E., Cox, J., Bond, L. (2013): How to mix? Spatial configurations, modes of production and resident perceptions of mixed tenure neighbourhoods. Cities, 35., 397-408. http://doi.org/f5hjmg

Kemény I., Janky B. (2003): A cigány nemzetiségi adatokról. Kisebbségkutatás, 2., 309-315.

Kemény I., Janky B. (2004): Települési és lakásviszonyok. Beszélo", 4., 96-111.

Kemény I., Janky B., Lengyel G. (2004): A magyarországi cigányság 1971-2003. Gondolat, MTA Etnikainemzeti Kisebbségkutató Intézet, Budapest

Kozma J. (2003): A szegénység pszichológiai vonatkozásai. Esély, 2., 15-30.

Kucsera Cs. (2008): Megalapozott elmélet: egy módszertan fejlődéstörténete. Szociológiai Szemle, 3., 92-108.

Kusmer, K. L. (1997): Ghettos real and imagined: A historical comment on Loic Wacquant's Three pernicious premises in the study of the American ghetto. International Journal of Urban and Regional Research, 4., 706-711. http://doi.org/cg4mpw

Ladányi J. (2009): A burkolt szelekciótól a nyilt diszkriminációig. MTA Történelemtudományi Intézet, MTA Társadalomkutató Központ, Budapest

Ladányi J. (2012): Leselejtezettek. A kirekesztett népesség társadalom- és térszerkezeti elhelyezkedésének átalakulása Magyarországon a piacgazdasági átmenet időszakában. L'Harmattan, Budapest

Ladányi J., Szelényi I. (2001): Van-e értelme az underclass kategória használatának? Beszélő, 11., 94-98.

Ladányi J., Szelényi I. (2004): A kirekesztettség változó formái. Napvilág Kiadó, Budapest

Ladányi J., Virág T. (2009): A szociális és etnikai alapú lakóhelyi szegregáció változó formái Magyarországon a piacgazdaság átmeneti időszakában. Kritika, 7-8., 2-8.

Lefebvre, H. (1991): The production of space. Basil Blackwell, Oxford

Lengyel G. (2006): Cigánytelepek egykor és ma. In: Kállai E., Törzsök E. (szerk.): Átszervezések kora. Cigánynak lenni Magyarországon Jelentés 2002-2006. Európa Összehasonlító Kisebbségkutatások Közalapítvány, Budapest, 56-91.

Lennert J., Kovács A. D., Farkas J. Zs., Bódi F. (2014): Lakóhelyi szegregáció a dél-alföldi mezővárosokban. Esély, 6., 3-19.

Letenyei L. (szerk) (2008): Településkutatás. Szöveggyüjtemény. Ráció Kiadó, Budapest

MacQueen, K. M., McLellan, E., Metzger, D. S., Kegeles, S., Strauss, R. P., Scotti, R., Blanchard, L., Trotter, R.T. II. (2001): What is community? An evidence-based definition for participatory public health. American Journal of Public Health, 12., 1929-1938. http://doi.org/ddgk32

Massey, D. S., Condran, G. A., Denton, N. A. (1987): The effect of residential segregation on black social and economic well-being. Social Forces, 1., 9-56.

Massey, D. S., Denton, N. (1993): American apartheid: Segregation and the making of the underclass. Harvard University Press, Cambridge

Massey, D. S., Denton, N. A. (1998): The missing link. Harvard University Press, Cambridge

Messing V., Molnár E. (2011a): Válaszok a pénztelenségre: szegény cigány és nem cigány családok megélhetési stratégiái. Esély, 1., 53-80.

Messing V., Molnár E. (2011b): Bezáródó kapcsolati hálók: szegény roma háztartások kapcsolati jellemzői. Esély, 5., 47-74.

Messing V. (2006): Lyukakból szőtt háló: háztartások közötti támogató kapcsolatok roma és nem roma szegények körében. Szociológiai Szemle, 2., 37-54.

Mugnano, S., Palvarini, S. (2013): "Sharing space without hanging together": A case study of social mix policy in Milan. Cities, 35., 417-422. http://doi.org/f5hkds 
NFGM (2012): Városfejlesztési Kézikönyv. Második, javitott kiadás. Nemzeti Fejlesztési és Gazdasági Minisztérium, Területfejlesztésért és Építésügyért Felelős Szakállamtitkárság, Budapest

Pataki Gy., Vári A. (szerk.) (2011): Részvétel - Akció - Kutatás. Magyarországi tapasztalatok a részvételi-, akció- és kooperatív kutatásokból. MTA Szociológiai Kutatóintézete, Budapest

Pászka I., Szűcs N. (2003): Kisebbségszociológia. Belvedere Meridionale, Szeged

Putnam, R. (1993): Making democracy work: Civic traditions in modern Italy. Princeton University Press, Princeton

Sen, A. K. (1999): Development as freedom. Oxford University Press, Oxford, New York

Siptár D., Tésits R. (2014): A szegénységi szegregáció területi jellegzetességei Baranya megyében. Human Innovation Review, 1-2., 139-162.

Solt Á. (2010): Élet a reményen túl. A szegregált telepen élők mentalitásvizsgálatának összegzése. Szociológiai Szemle, 3., 100-133.

Stewart, M. S. (2001): Depriváció, romák és az underclass. Beszélő, 7-8., 82-94.

Szilvási L. (2008): Gyermekszegénység és társadalmi kirekesztettség Magyarországon. In: Sallai É. (szerk.): Társadalmi egyenlőtlenségek, a nem hagyományos családmodell, a szülői viselkedés és a gyermekek fejlődésének összefüggései. Educatio Társadalmi Szolgáltató Közhasznú Társaság, Budapest, 165-174.

Szoboszlai Zs. (2004): Szegénység, marginalizáció, szegregáció. Tér és Társadalom, 3., 25-42.

Szuhay P. (1999): A magyarországi cigányság kultúrája: etnikus kultúra vagy a szegénység kultúrája. Panoráma, Budapest

Váradi M. M., Virág T. (2015): A térbeli kirekesztés változó mintái vidéki terekben. Szociológiai Szemle, 1., 89-113.

Wacquant, L. (2001): Deadly symbiosis - When ghetto and prison meet and mesh. Punishment and Society, 1., 95-133. http://doi.org/fkvvmj

Wacquant, L. (2004): What is a ghetto? Constructing a social concept. In: Smelser, N. J., Baltes, P. B. (eds.): International encyclopedia of the social and behavioral sciences. Pergamon Press, London, 1-7. http://doi.org/dv6prk

Wacquant, L. (2008): Urban outcasts: A comparative sociology of advanced marginality. Polity, Cambridge Woolcock, M., Narayan, D. (2000): Social capital: Implications for development theory, research and policy. The World Bank Research Observer, 2., 225-249. http://doi.org/q38 